From experimental work on the biogenesis of the tropane alkaloids some speculations have been made, and the results appear to indicate that the product of synthesis is related to the site of synthesis. The histochemical evidence for alkaloid production in meristematic tissues has been corroborated, and two other workers directed attention towards the root as the locus of alkaloid synthesis. Reciprocal grafts between tetraploid and diploid Datura stramonium have been made, and it was suggested that the genetical nature of the stock determines the alkaloidal content of scion and stock. In branch chimæras the tetraploid branch is richer in alkaloid than the diploid branch growing on the same root.

One curious fact has come to light as a result of a study of the anthraquinone glycosides of cascara, namely, that galenical preparations containing glycosides in amounts similar to those found in the crude drug are only half as active. The use of boiling water and autoclaving was stated to be a more efficient method of producing the dry extract of cascara than extraction with cold water ; apparently, evaporation of the percolate under reduced pressure does not enhance the potency of the final product.

The use of dihydrostreptomycin and of penicillin as a mixed preparation raises an assay problem, and it has been established that the success of any micro. biological method must depend on the absence of interference by dihydrostreptomycin. A further paper related to the origin of stimulation zones on penicillin assay plates, and attributed the cause, in part, to additional nutrients having diffused from the inhibition zones.

A method was described using small groups of guinea pigs for demonstrating the prolonged action of globin insulin and protamine zinc insulin. The guinea pig was recommended as a satisfactory test animal, whereas this demonstration cannot be carried out with the rabbit. Another paper compared the efficiency of two official pyrogen tests, and suggested that the further use of rabbits, which had once been used in a test in which pyrogen had been found, should be forbidden. The maximum degree of restraint which may be imposed on the rabbits should be specified and electrical thermometers should be used.

The work of several contributors was focused on the stability of some pharmaceutical preparations. Methods of assessing the chemical stability of procaine benzyl-penicillin in aqueous media were described. A study of different batches of vitamin $B_{12}$ injections has shown that differences in potency are caused by exposure to daylight. Although copper is known to affect the stability of aneurine hydrochloride solution, it was pointed out that the same effect is greatly diminished in dry powders when stored at room temperature over long periods. The problem of assessing emulsion stability was considered, and the breakdown has been investigated over the temperature range $4-85^{\circ} \mathrm{C}$. It is considered that globule-size frequency analysis yields a reliable picture of the internal state of the emulsion. Elevated temperature was proposed as an artificial breakdown stress for the evaluation of emulsion stability.

Pharmacological research on some synthetic drugs was reported, and one substance has proved of value as a substitute for $p$-amino-salicylic acid, appearing to delay the emergence of streptomycin resistance. A structural analogue of hydrocortisone has been prepared and found to inhibit the glyconeo-genetic activity of cortisone acetate in adrenalectomized rats.
Further research has been carried out on bacterial survival in systems of low moisture content, and oils suitable for use in 'sterility tests' have been ingeniously prepared. A limiting viable count technique has been modified. Also reported was the fact that, by using soluble surface-active agents in small amounts, cotton dressings will retain their absorbency better than the conventional type. Three papers read at the Conference made a useful contribution to the problem of evaluating antacids, and a further paper described a rapid method of determining calcium and magnesium by titration.

For many years pharmacists have been 'glass conscious' and aware of the necessity of controlling its quality and characteristics when used as containers for pharmaceutical preparations. With the latter comment one paper was introduced as a contribution to the symposium session, which dealt with the pharmaceutical aspects of glass and rubber Experiences with containers and closures in the pharmaceutical industry were also discussed.

S. B. Challen

\section{MOVEMENT OF POSTGRADUATE SCIENCE STUDENTS}

$\mathrm{A}$ MONG the activities of the British Council which are of direct interest to science none is more important than its encouragement of the movement of scientists, by bringing to Great Britain scientists, both postgraduates for purposes of advanced study or research, and more senior people to visit their opposite numbers, and by arranging for British scientists to pay lecturing or advisory visits overseas. This flow of scientists is, of course, only part of such movements, and because the funds available to the British Council for these purposes are limited, it is essential that they should be deployed in those directions where the need is greatest. This cannot be done effectively without a reasonably accurate knowledge of the flow of scientists promoted by other sources. Various publications indicate the awards available; but hitherto there have been no statistics showing the extent and characteristics of the flow which actually occurs.

For this reason the Executive Committee of the British Council in November 1951 agreed to the appointment of a working party of representatives of the Council itself, the Royal Society, the Department of Scientific and Industrial Research and the Medical and the Agricultural Research Councils, to review broadly and report on existing facilities for the movement of scientists, so as to arrive at a measure of the present scale of such activities, and to explore the need for any further co-ordination. The working party consisted of Sir Alfred Egerton, Dr. D. C. Martin, Dr. Alexander King, Mr. W. G. Alexander, Dr. F. H. K. Green (who withdrew later since in his opinion the examination was unlikely to yield data of use to medicine) and Sir Kenneth Loch, and it selected the calendar year 1951 as a sample period, deciding also to limit the investigation to the movement of graduate scientists whose journeys were made for the purpose of either advanced study or research. Assistance was sought from British universities, official bodies, trust funds and other organizations known to have an interest in this type of movement. For each individual information was collected on the professional status 
Table 1. No. of Postgraduate Stodents enthring Great Britain in 1951

\begin{tabular}{|c|c|c|c|c|c|c|c|c|}
\hline & $\begin{array}{l}\text { Physical } \\
\text { sciences }\end{array}$ & $\begin{array}{l}\text { Biological } \\
\text { sciences }\end{array}$ & $\begin{array}{c}\text { Bacteriology, } \\
\text { biochemistry, } \\
\text { pathology }\end{array}$ & Medicine & Engineering & Agriculture & Miscellaneous & Total \\
\hline \multirow[t]{2}{*}{$\begin{array}{l}\text { Commonwealth } \\
\text { Australia, New Zealand } \\
\text { India, Pakistan, Ceylon } \\
\text { South Africa } \\
\text { Canada } \\
\text { Colonies }\end{array}$} & $\begin{array}{r}50 \\
47 \\
10 \\
37 \\
4\end{array}$ & $\begin{array}{r}15 \\
17 \\
2 \\
8 \\
1\end{array}$ & $\begin{array}{r}13 \\
23 \\
6 \\
2\end{array}$ & $\begin{array}{l}28 \\
63 \\
18 \\
23 \\
22\end{array}$ & $\begin{array}{r}28 \\
86 \\
20 \\
18 \\
5\end{array}$ & $\begin{array}{l}3 \\
7 \\
2 \\
1 \\
5\end{array}$ & $\begin{array}{r}2 \\
3 \\
- \\
-\end{array}$ & $\begin{array}{r}139 \\
246 \\
58 \\
87 \\
39\end{array}$ \\
\hline & 148 & 43 & 44 & 154 & 157 & 18 & 5 & 569 \\
\hline \multirow[t]{2}{*}{$\begin{array}{l}\text { Foreign } \\
\text { Europe } \\
\text { Middle East } \\
\text { Far East } \\
\text { Latin America } \\
\text { U.S.A. }\end{array}$} & $\begin{array}{r}76 \\
30 \\
6 \\
4 \\
46\end{array}$ & $\begin{array}{r}13 \\
8 \\
3 \\
2 \\
9\end{array}$ & $\begin{array}{r}19 \\
6 \\
4 \\
4 \\
6\end{array}$ & $\begin{array}{l}92 \\
47 \\
17 \\
41 \\
29\end{array}$ & $\begin{array}{r}44 \\
30 \\
10 \\
7 \\
9\end{array}$ & $\begin{array}{r}16 \\
10 \\
3 \\
7 \\
\end{array}$ & $\begin{array}{l}\mathbf{5} \\
\mathbf{1} \\
1 \\
1 \\
-\end{array}$ & $\begin{array}{r}265 \\
132 \\
44 \\
66 \\
99\end{array}$ \\
\hline & 162 & 35 & 39 & 226 & 100 & 36 & 8 & 606 \\
\hline Total & 310 & 78 & 83 & 380 & 257 & 54 & 13 & 1,175 \\
\hline
\end{tabular}

Table 2. No. of Posteraddate Students leaving Grgat Britain for Study abroad in 1951

\begin{tabular}{|c|c|c|c|c|c|c|c|c|}
\hline & $\begin{array}{l}\text { Physical } \\
\text { sciences }\end{array}$ & $\begin{array}{l}\text { Biological } \\
\text { sciences }\end{array}$ & $\begin{array}{c}\text { Bacteriology, } \\
\text { biochemistry, } \\
\text { pathology }\end{array}$ & Medicine & Engineering & Agriculture & Miscellaneous & Total \\
\hline $\begin{array}{l}\text { Commonwealth } \\
\text { Australia, New Zealand } \\
\text { India, Pakistan, Ceylon } \\
\text { South Africa } \\
\text { Canada } \\
\text { Colonies }\end{array}$ & $\begin{array}{r}1 \\
3 \\
2 \\
18 \\
5\end{array}$ & $\begin{array}{l}5 \\
7 \\
4 \\
7\end{array}$ & $\frac{2}{\frac{4}{1}}$ & $\begin{array}{r}5 \\
1 \\
14\end{array}$ & $\begin{array}{r}3 \\
1 \\
\overrightarrow{14} \\
\end{array}$ & $\underset{\underline{1}}{\overrightarrow{2}}$ & $\bar{z}$ & $\begin{array}{r}18 \\
12 \\
2 \\
55 \\
18\end{array}$ \\
\hline \multirow{3}{*}{$\begin{array}{l}\text { Foreign } \\
\text { Europe } \\
\text { Middle East } \\
\text { Far East } \\
\text { Africa (ex. Egypt, Sudan } \\
\text { latin America } \\
\text { Arctic } \\
\text { U.S.A. }\end{array}$} & 29 & 23 & 7 & 24 & 18 & 3 & 1 & 105 \\
\hline & $\begin{array}{r}5 \cdot \frac{7}{7} \\
11 \\
3 \\
5 \\
59\end{array}$ & $\begin{array}{r}18 \\
2 \\
-\overrightarrow{3} \\
6 \\
1 \\
9\end{array}$ & $\begin{array}{l}\frac{12}{二} \\
= \\
21\end{array}$ & $\begin{array}{r}41 \\
1 \\
1 \\
1 \\
- \\
60\end{array}$ & $\begin{array}{l}20 \\
\frac{1}{-} \\
= \\
=\end{array}$ & $\begin{array}{l}23 \\
\vec{z} \\
= \\
41\end{array}$ & $\begin{array}{l}\vec{z} \\
\vec{z} \\
\overrightarrow{2}\end{array}$ & $\begin{array}{r}165 \\
11 \\
1 \\
15 \\
9 \\
6 \\
220\end{array}$ \\
\hline & 136 & 39 & 33 & 104 & 49 & 64 & 2 & 427 \\
\hline Total & 165 & 62 & 40 & 128 & 67 & 67 & 3 & 532 \\
\hline
\end{tabular}

of the scientist, his subject, the broad purpose and duration of his visit, and the country concerned.

Thanks to the willing and helpful co-operation of those approached, information was collected and analysed on the movements of more than five hundred scientists from Britain and some eleven hundred visiting Britain. It is believed that the survey covers more than 80 per cent of the total movements of this type, and that it is thus sufficiently comprehensive to give a useful cross-section of the whole flow. The statistics thus obtained are summarized in a series of tables, of which those relating to the movements to Britain and from Britain in $195 \mathrm{l}$ by groups of countries and groups of subjects and to the comparative flow of scientists are reproduced as Tables 1 and 2, respectively, herewith. Of scientists visiting Britain from Commonwealth countries, 30 per cent stayed for more than three and less than thirteen months, and 55 per cent more than thirteen and less than twenty-five months; for scientists coming from foreign countries, the corresponding figures are 36 and 26 per cent, respectively, while 22 per cent stayed for less than one month. Of scientists going from Britain to Commonwealth countries, on the other hand, 35 per cent stayed for more than one but less than three months, and 39 per cent for more than three and less than thirteen months; for those going to foreign countries the corresponding figures are 22 and 42 per cent, respectively, while 30 per cent stayed for less than one month. The British Council offers to place selected information at the disposal of other bodies interested in the movement of scientists ; inquiries should be addressed to Administrator, Science Group, British Council, 65 Davies Street, London, W.1. It is also recommended that British Council representatives should be provided with the survey data relating to their country and those contiguous to it.

It is apparent from the survey that the saturation point of useful effort in the movement of scientists has not been reached. Thus in Latin American countries, where science is of recognized importance, comparatively little was being done; but in others, such as Egypt, the effort seems to be adequate. At home the effort is limited by the number of vacancies which could be made available at universities and technical colleges for postgraduate research workers or students from overseas. It is unlikely that offers from authorities abroad would in themselves be sufficiently attractive to British postgraduates for them to wish to work in those countries, and hence, owing to the advantages which would also accrue to Britain, provision should be made for any financial assistance required.

The working party found some difficulty in suggesting any practical way of analysing attendances at conferences. Although it is of opinion that Britain should be better represented at scientific conferences abroad, particularly in more distant countries, the effect of the recent Treasury relaxation of currency restrictions for British scientists attending conferences 
in many countries could not be judged. In view of all the factors, the working party recommends that consideration of the question of greater facilities for the attendance of scientists at conferences should be deferred until the report of the Drogheda Committee is available.

\section{SUPPLY AND EDUCATION OF MANAGERS FOR BRITISH INDUSTRY}

A

BOOKLET issued by the British Institute of Management contains the text of speeches delivered at the Second Scottish Conference held at Gleneagles during April 10-12. Among the subjects debated was that of finding the next generation of managers for British industry, and Dr. N. C. Hunt, referring to the figures supplied by Dr. E. Ashby, which indicate that industry will in future have to recruit its managerial staff from the universities because the reservoir of highly intelligent young people available outside the universities is drying up, discussed the kind of education and training which should be given to university students.

In his paper Dr. Hunt pointed out that, of hundreds of departments of business administration in the United States, only thirty are recognized by the Association of American Universities, and even if it does not matter what subjects are studied in developing the qualities desirable for administration, all subjects are not of equal value in giving the knowledge required. So long as normal university standards of teaching and research are maintained, Dr. Hunt thinks administrative studies could reasonably be included in a university curriculum. Postgraduate training might be given immediately after graduation or after some years of industrial experience; while the short courses offered at the Administrative Staff College, Henley-on-Thames, are extremely useful, they are not the whole answer, especially for the more junior executive who lacks the experience to profit from a course deriving its value from the interchange of experience rather than from formal study. There are already postgraduate courses in business administration at the Universities of London and Manchester and one is under consideration at Edinburgh, while there is a Department of Engineering Production at Birmingham. Dr. Hunt maintained that only in a university could be found the departments specializing in the basic disciplines out of which administration springs-economics, psychology, sociology, law and the applied sciences-and it is upon these that an advanced school of administration must be built.

In emphasizing that education for management must be a co-operative effort between the teaching institutions and industry, Dr. D. S. Anderson pointed out that in practice this means that industry must be willing to lend staff for lecturing in management courses ; to accept trainees for long or short periods ; and to take the trouble to arrange proper schemes of training as well as to supply frank particulars of successful and unsuccessful experiments and to second staff from time to time for further training. It also involves willingness on the part of academic staff to keep up to date by maintaining close contacts with industry, or even to return to industry for periods of 'refreshment', and that industry should be prepared to put some consulting work in the way of academic institutions because of the value which such work has in keeping a teaching staff in touch with actual practice. The content of courses does not present any serious problem; but it is essential that the various kinds of courses should not be limited to managers or potential managers, but should also provide for the training of workers' representatives. Dr. Anderson continued by saying that intelligent discussion -for example, in joint consultation-means intelligence on both sides of the table, and he thinks that only by education and training could one remove the feeling of inferiority to which lack of co-operation is so often due.

\section{SUSCEPTIBILITY OF THE GUINEA PIG TO PHARMACOLOGICAL FACTORS FROM ITS OWN SERUM}

\author{
By Drs. M. E. MACKAY*, A. A. MILES, C.B.E., \\ M. SCHACHTER and D. L. WILHELM
}

Lister Institute of Preventive Medicine, London, S.W.I

$\mathrm{D}^{\mathrm{T}}$ URING a search in the guinea pig for endogenous substances responsible for the vascular and toxic phenomena of inflammation, we discovered in the blood serum of that animal a number of striking pharmacological activities, apparently due to substances of high molecular weight. Serum and serum. fractions proved to contain substances increasing the permeability of skin capillaries (permeability factors; PF), lowering the blood pressure (hypotensive factor; HF), and decreasing the smooth muscle contractor action of histamine (anti-histamine factors; AHF). None of these substances is demonstrable in fresh undiluted serum, but two are activated when the serum is diluted in 0.85 per cent saline: a permeability factor, $\mathrm{PF} / \mathrm{Dil}$; and an antihistamine factor, AHF/Dil. A second permeability factor accumulates in undiluted serum which has been held for several days at $2^{\circ} \mathrm{C}$.; that is, on ageing of the serum. This we designate PF/Age.

$P F / D i l$. When $0 \cdot 1-\mathrm{ml}$. volumes of serial dilutions of fresh serum are injected intracutaneously into depilated albino guinea pigs with pontamine blue in their circulation ${ }^{1}$, within three minutes capillary permeability is substantially increased and the dye exudes into the injection site to form a circular blue lesion. Serum is activated only when it is diluted beyond 1/15-1/30. Maximum activation, as indicated by maximum average diameter of lesion, occurs at $1 / 100-1 / 400$, and the activity is diluted out at about $1 / 5,000$ (Fig. 1). The dilution effect is evident even in the animal from which the serum is obtained. The activation is to some extent reversible, because when diluted serum is reconcentrated at $2^{\circ} \mathrm{C}$. by filtration of the saline through cellophan, it partly regains its inactivity. Unlike substances such as histamine or the histamine-liberator $48 / 80^{1}$, the factor is not antagonized by mepyramine given in intra-peritoneal doses of $20 \mathrm{mgm}$. $/ \mathrm{kgm}$. body-weight two hours before the test. It is relatively heat-labile, a 2 per cent solution of serum being largely inactivated by heating for $1 \mathrm{~min}$. at $100^{\circ} \mathrm{C}$.

\footnotetext{
* Working on behalf of the Medical Research Council.
} 